\title{
Simplified in vitro propagation protocol for Tacca leontopetaloides (L.) Kuntze and assessment of genetic uniformity of regenerated plantlets
}

\author{
Petra Hlasna Cepkova', Jan Vitamvas², Iva Viehmannova ${ }^{1 *}$, Jana Kisilova1, Eloy Fernandez Cusimamani', \\ Luigi Milella ${ }^{3}$ \\ ${ }^{1}$ Department of Crop Sciences and Agroforestry, Faculty of Tropical AgriSciences, Czech University of Life Sciences Prague, Kamycka 129, \\ Prague 165 21, Czech Republic; ${ }^{2}$ Department of Forest Ecology, Faculty of Forestry and Wood Sciences, Czech University of Life Sciences \\ Prague, Kamycka 129, Prague 165 21, Czech Republic; ${ }^{3}$ Department of Sciences (Sciences instead of Science), University of Basilicata, Viale \\ dell'Ateneo Lucano 10, Potenza 851 00, Italy
}

\section{A B S T R A C T}

\begin{abstract}
Tacca leontopetaloides is a tuberous species with nutritional, medicinal, and industrial potential. The aim of the present study was to develop a simplified micropropagation protocol for this species, combining phases of in vitro propagation and rooting, and to assess the genetic stability of in vitro regenerants using ISSR and flow cytometric analysis. In the first step, the effect of four cytokinins (BA, zeatin, kinetin, thidiazuron) at concentrations of $0.1-0.7 \mathrm{mg} \mathrm{l}^{-1}$ on shoot organogenesis was tested. The highest number of shoots was achieved on MS medium supplemented with $0.1 \mathrm{mg} \mathrm{l}^{-1}$ zeatin ( $4.11 \pm 0.35$ shoots/explant). Thereafter, this treatment was combined with auxins (NAA, IAA) at concentrations of 0.01-0.07 $\mathrm{mg} \mathrm{l}^{-1}$ to study shoot organogenesis and in vitro rooting. A combination of plant growth regulators provided unchanged (high) shoot organogenesis, while the root number per explant increased. The highest number of roots of all tested treatments was produced on MS medium supplemented with zeatin $\left(0.1 \mathrm{mg} \mathrm{l}^{-1}\right)$ in combination with NAA $\left(0.05 \mathrm{mg} \mathrm{l}^{-1}\right)(5.00 \pm 0.38$ roots/explant), suggesting that this medium may be used for both propagation and rooting. Well-rooted plants were transferred ex vitro, with a $97.78 \%$ survival rate. Ten randomly chosen in vitro regenerants were subjected to ISSR and flow cytometric analysis. Eleven ISSR primers produced 40 clear and reproducible bands per sample. All amplified products were monomorphic; no polymorphism was detected. Similarly, the results of flow cytometric analysis showed no variation in ploidy level. Thus, the micropropagation method optimized here can be used for highly effective production of true-to-type plants of T. leontopetaloides.
\end{abstract}

Keywords: Dioscoreaceae; Flow cytometry; Genetic fidelity; Micropropagation; Molecular marker; Tacca

\section{INTRODUCTION}

Tacca leontopetaloides, also known as Polynesian arrowroot, is a perennial herb belonging to the family Dioscoreaceae. This species is native to western Africa, Southeast Asia, and northern Australia, and it is known to have been domesticated in the Pacific Islands by the local inhabitants (Ukpabi et al., 2009; Ubwa et al., 2011). Tuberous rhizomes of T. leontopetaloides contain 10-25\% of starch, and they serve as an important food source for many Pacific Island cultures (Ukpabi et al., 2009; Kay, 1987; Spennemann, 1994). In some of the islands, the starch is used in the textile field for fabric stiffening. The bitter tubers are eaten raw to treat stomach ailments (diarrhoea and dysentery) (Kay, 1987). Recently, T. leontopetaloides has attracted attention from the researchers as a potential new starch source for biodegradable plastics (Makhtar et al., 2013).

This plant of multiple uses can be propagated via its seeds, but this has apparently never been practised by the farmers as the seeds have a poor germination capacity. In horticultural tradition, tuber- or shoot-propagated plants dominate (Spennemann, 1994; Borokini et al., 2011). However, this technique is incapable of producing high numbers of plants for large-scale propagation.

In vitro culture techniques ensure rapid multiplication of the plant material and production of large numbers of plantlets in a short time (Engelmann, 2011). Previously, micropropagation protocols have been optimized for

\footnotetext{
*Corresponding author:

Iva Viehmannova, Department of Crop Sciences and Agroforestry, Faculty of Tropical AgriSciences, Czech University of Life Sciences Prague, Kamycka 129, Prague 165 21, Czech Republic. E-mail: viehmannova@gmail.com
} 
many species of the Dioscoreaceae family, e.g., Dioscorea zingiberensis (Chen et al., 2003), D. fordii (Yan et al., 2011), and D. multiflora (de Souza et al., 2011). Specifically, in the Tacca genus, protocols for shoot organogenesis have been proposed for T. chantrieri (Charoensub et al., 2008), and T. leontopetaloides (Borokini et al., 2011). These primary studies verified the potential of Tacca plants' response to in vitro cultures and provided valuable data for further research. In the latter study, the effect of 6-benzyladenine (BA) on shoot proliferation was tested. However, it can be presumed that another cytokinin might provide even more satisfactory results. Additionally, the potential occurrence of somaclonal variation was not studied among the in vitro regenerants. Overall, this step is considered as crucial, as somaclonal variation might be a potential drawback of the in vitro propagation process (Adhikari et al., 2014).

Thus, the aim of this study was to optimize a simplified timeefficient micropropagation protocol for T. leontopetaloides, enabling both in vitro propagation and rooting in one step, as well as to assess the genetic fidelity of in vitro regenerants using ISSR and flow cytometry. The protocol developed might be used for effective propagation of this species with nutritional, medicinal, and industrial potentials.

\section{MATERIALS AND METHODS}

\section{Plant material and establishment of in vitro culture}

In vitro cultures of $T$. leontopetaloides were established from seeds, obtained from the Botanical Garden of the Faculty of Tropical AgriSciences, Czech University of Life Sciences Prague. The seeds were surface sterilized using $70 \%$ ethanol for $1 \mathrm{~min}$, and $2 \% \mathrm{NaClO}$ for $20 \mathrm{~min}$. Thereafter, the seeds were rinsed three times with sterile distilled water, and then sown onto half-strength MS medium (Murashige and Skoog, 1962) supplemented with $1 \mathrm{mg} \mathrm{l}^{-1}$ thiamine, $100 \mathrm{mg} \mathrm{l}^{-1}$ myo-inositol, $30 \mathrm{~g} \mathrm{l}^{-1}$ sucrose and $8 \mathrm{gl}^{-1}$ agar. One hundred $\mathrm{ml}$ Erlenmeyer flasks containing $30 \mathrm{ml}$ of medium were used to culture the explants. The medium was adjusted to $\mathrm{pH} 5.7$ and it was autoclaved at $121^{\circ} \mathrm{C}$, in $1.1 \mathrm{~atm}$, for $20 \mathrm{~min}$. The cultures were incubated at $25 / 23{ }^{\circ} \mathrm{C}$ under a $16 / 8 \mathrm{~h}$ light/dark regime, and at a photosynthetic photon flux density of $35 \mu \mathrm{mol} \mathrm{m}{ }^{-2} \mathrm{~s}^{-1}$, provided by cool-white fluorescent tubes. After seed germination, root part of the seedling was removed and the plants were transferred onto solid MS medium. The plants were regularly subcultivated every 28 days on the same medium and via shoot organogenesis, sufficient plant material for the experiment was obtained.

\section{Effect of cytokinins on shoot organogenesis}

Shoots growing from the basal part of the explant, 0.3-0.5 cm long, were used as explants. In this experiment, different cytokinins at various concentrations were tested. Kinetin, BA, zeatin, and thidiazuron (TDZ) at concentrations of $0.1,0.3,0.5$, or $0.7 \mathrm{mg} \mathrm{l}^{-1}$ were added to the MS medium containing $1 \mathrm{mg} \mathrm{l}^{-1}$ thiamine, $100 \mathrm{mgl}^{-1}$ myoinositol, $30 \mathrm{gl}^{-1}$ sucrose and $8 \mathrm{gl}^{-1}$ agar ( $\mathrm{pH}$ 5.7). As a control, medium without plant growth regulators (PGRs) was used. Cultures were maintained in the culture conditions, as described above. Ten explants in two replications were used for evaluation of each treatment. Shoot formation was evaluated after eight weeks of cultivation.

\section{Effect of combination of cytokinin and auxin on shoot organogenesis and in vitro rooting}

Auxins $\alpha$-naphthalenacetic acid (NAA) and indole-3-acetic acid (IAA) at concentrations of $0.01,0.03,0.05$, and $0.07 \mathrm{mg} \mathrm{l}^{-1}$ were tested in combination with $0.1 \mathrm{mg} \mathrm{l}^{-1}$ zeatin (the most effective cytokinin in the previous experiment). As a control, medium without plant growth regulators was used. For this experiment, MS medium supplemented with $1 \mathrm{mg} \mathrm{l}^{-1}$ thiamine, $100 \mathrm{mg} \mathrm{l}^{-1}$ myo-inositol, $30 \mathrm{~g} \mathrm{l}^{-1}$ sucrose and $8 \mathrm{~g}^{-1}$ agar ( $\mathrm{pH}$ 5.7) was used. Culture conditions were identical to those described above. Ten explants in two replications were used for the evaluation of each treatment. The numbers of roots and shoots were evaluated after eight weeks of in vitro cultivation. Ten randomly selected plants from the most efficient treatment were subjected to ISSR and flow cytometry to reveal potential somaclonal variation after the process of in vitro regeneration.

\section{Ex vitro transfer}

In total, 90 well-rooted plants (obtained by repeated subcultivation of explants on the medium containing $0.1 \mathrm{mg} \mathrm{l}^{-1}$ zeatin and $0.05 \mathrm{mg} \mathrm{l}^{-1} \mathrm{NAA}$ ) were removed from Erlenmeyer flasks. The roots were rinsed with tap water to remove traces of any adhering medium. Subsequently, the plants were transferred to $6 \mathrm{~cm}$ pots containing a sterilized mixture of garden substrate and perlite (1:1). The cultures were covered with transparent polyethylene foil to maintain high air humidity (70-90\%), temperature (ca. $25 / 20{ }^{\circ} \mathrm{C}$ day/night), and placed in a greenhouse. After 3 weeks, the foil was gradually removed; from the 4th week, the plants were exposed to normal greenhouse culture conditions (60-70\% air humidity, temperature ca. $20 / 17^{\circ} \mathrm{C}$ day/night). The survival rate of the plants was recorded 8 weeks after ex vitro transfer.

\section{DNA extraction and ISSR analysis}

Ten randomly chosen plants cultivated on medium containing $0.1 \mathrm{mg} \mathrm{l}^{-1}$ zeatin and $0.05 \mathrm{mg} \mathrm{l}^{-1} \mathrm{NAA}$, plus a control plant cultivated on MS medium, were analysed. DNA was extracted from approximately $100 \mathrm{mg}$ of young healthy leaves using the CTAB method (Doyle and Doyle, 1987). 
At the first stage, 30 ISSR primers (University of British Columbia, UBC, USA) were tested for further analyses on the control plant. A set of 17 ISSR primers that recorded scorable clear bands with a great intensity were used for the genetic stability screening. DNA amplifications using Polymerase Chain Reaction (PCR) were carried out in a reaction volume of $20 \mu \mathrm{l}$ with the following composition: $10 \mu \mathrm{l}$ of $2 \mathrm{x}$ PPP Master Mix (150 mM Tris-HCl, $\mathrm{pH} 8.8\left(25^{\circ} \mathrm{C}\right), 40 \mathrm{mM}(\mathrm{NH} 4)_{2} \mathrm{SO}_{4}, 0.02 \%$ Tween 20 ,

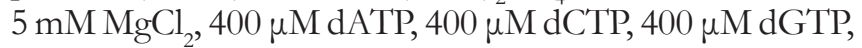
$400 \mu \mathrm{M}$ dTTP, $100 \mathrm{U} / \mathrm{ml}$ Taq-Purple DNA polymerase, monoclonal antibody anti-Taq $(38 \mathrm{nM})$, and stabilisers and additives; Tob-Bio, Czech Republic), $7.3 \mu$ of PCR $\mathrm{H}_{2} \mathrm{O}$ (Top-Bio, Czech Republic), $2 \mu \mathrm{l}$ of template DNA (20 $\mathrm{ng} / \mu \mathrm{l}), 0.5 \mu \mathrm{l}$ of primer $(0.1 \mu \mathrm{M})$ and $0.2 \mu \mathrm{l}$ of BSA $(20 \mathrm{mg} / \mathrm{ml}$ ) (Fermentas, Germany). The ISSR analysis was carried out by use of a QB96 Server Gradient Thermal Cycler (Quanta Biotech, United Kingdom). Annealing temperatures in the PCR were optimized for each primer. The cycling conditions were as follows: initial denaturation step for 5 min at $94^{\circ} \mathrm{C}$, followed by 40 cycles of 1 min at $94^{\circ} \mathrm{C}$ (denaturing), $1 \mathrm{~min}$ at specific annealing temperature (Table 3), $2 \mathrm{~min}$ at $72{ }^{\circ} \mathrm{C}$ (extension), and 1 cycle for a 10 min final extension step at $72{ }^{\circ} \mathrm{C}$. PCR products at a volume of $6 \mu \mathrm{l}$ were electrophoretically separated using $2 \%$ agarose gel in $1 \times$ TBE buffer for about $3 \mathrm{~h}$ at $55 \mathrm{~V}$. DNA amplification products were stained with $\mathrm{SYBR}^{\circledR}$ Safe DNA Gel Stain (Invitrogen, USA). The amplified fragments were scored either a presence (1) or absence (0) for each regenerant and control plant.

\section{Flow cytometric analysis}

A CyFlow Space flow cytometer (Partec GmbH, Münster, Germany) was employed for the flow cytometric analysis. The two-step methodology according to Dolezel et al. (2007) was used for the sample preparation. About $0.5 \mathrm{~cm}^{2}$ of T. leontopetaloides leaf and an appropriate amount of internal reference standard (Glycine max cv. Polanka, 2C $=2.50$ pg; Dolezel et al., 1994) were chopped in $0.5 \mathrm{ml}$ of ice-cold Otto I buffer $(0.5 \%$ (v/v) Tween $20,0.1 \mathrm{M}$ citric acid) using a razor blade. To filter the suspension, $42-\mu \mathrm{m}$ nylon mesh was used. Thereafter, the sample was incubated for $10 \mathrm{~min}$ at room temperature. The filtrate was stained with a solution consisting of $1 \mathrm{ml}$ of Otto II buffer $\left(0.4 \mathrm{M} \mathrm{Na}_{2} \mathrm{HPO}_{4} \cdot 12 \mathrm{H}_{2} \mathrm{O}\right), 4 \mu \mathrm{g} \mathrm{m}^{-1}$ AT-selective fluorescent dye 4',6-diamino-2-phenylindole and $2 \mu \mathrm{ml}^{-1}$ $\beta$-mercaptoethanol. After incubation of the samples at room temperature for $5 \mathrm{~min}$, the stained nuclei were analysed with a flow cytometer at a concentration of 5,000 per sample. The obtained histograms were evaluated using the FloMax software (ver. 2.4d; Partec GmbH, Münster, Germany). For each analysed sample, the DNA-ratios were counted by dividing the mean of the G0/G1 peak of the Tacca sample by the mean of the G0/G1 peak of the internal standard. The coefficitent of variation of the G0/G1 peaks was also recorded.

\section{Statistical analysis}

The in vitro experiments were set up in a completely randomized design. Statistical analysis of the data obtained from the micropropagation experiment was performed using one-way ANOVA, and the significant differences between means were assessed by Duncan's multiple range test $(\mathrm{P} \leq 0.05)$ [StatSoft STATISTICA 12.0].

\section{RESULTS AND DISCUSSION}

\section{Effect of cytokinins on shoot organogenesis}

In the first phase of the experiment, the effect of four types of cytokinins (BA, zeatin, kinetin, and TDZ) at different concentrations on shoot organogenesis was studied. A specific response was obtained for the tested cytokinins at their various concentrations.

Overall, zeatin proved to be the most efficient cytokinin, which at a concentration of $0.1 \mathrm{mg} \mathrm{l}^{-1}$ provided a significantly higher number of new shoots $(4.11 \pm 0.35)$ compared to other treatments (Table 1). Formation of the first new shoots started after 14 days of cultivation, and proceeded throughout further cultivation. Low concentrations of zeatin $\left(0.1\right.$ and $\left.0.3 \mathrm{mg} \mathrm{l}^{-1}\right)$ produced shoots of normal healthy appearance without any morphological abnormalities (Fig. 1a), comparably to the control treatment. Nevertheless, in contrast to the control, the number of shoots was higher, and their development was more rapid on medium containing zeatin. The development of abnormal leaves was observed from a concentration of $0.5 \mathrm{mg} \mathrm{l}^{-1}$, resulting in decreasing shoot formation, and followed by callus formation. This tendency was even more evident at the highest concentration used (0.7 $\mathrm{mg} \mathrm{l}^{-1}$ zeatin).

Previously, for shoot formation of T. leontopetaloides, BA was reported to be the optimal cytokinin (Borokini et al., 2011). However, this study did not provide any comparison among various cytokinins. In our experiment, although BA showed a positive effect on shoot formation, especially at concentrations 0.5 and $0.7 \mathrm{mg} \mathrm{l}^{-1}(2.00 \pm 0.25$, and $2.16 \pm 0.65$, respectively), no BA concentration exceeded the effect of $0.1 \mathrm{mg} \mathrm{l}^{-1}$ zeatin (Table 1). Moreover, it was observed that higher BA concentrations tended to develop small, morphologically abnormal leaves, dark green with a thicker petiole. Later on, a whitish green compact callus developed in these treatments. Comparable to our study, in many species from various botanical families, e.g., Drosera intermedia (Rejthar et al., 2014), or Thermopsis turcica (Tekdal and 
Table 1: Effect of different cytokinins on shoot production in $T$. leontopetaloides after eight weeks of in vitro cultivation

\begin{tabular}{|c|c|c|c|c|c|}
\hline \multicolumn{4}{|c|}{$\begin{array}{l}\text { PGR concentration } \\
\left(\mathrm{mg} \mathrm{l}^{-1}\right)\end{array}$} & \multirow{2}{*}{$\begin{array}{c}\text { Number of } \\
\text { shoots/explant } \\
\text { (mean } \pm \text { S.E.) }\end{array}$} & \multirow{2}{*}{$\begin{array}{l}\text { Remark (C-callus } \\
\text { induction; } \\
\mathrm{N} \text {-necrosis) }\end{array}$} \\
\hline BA & Zeatin & Kinetin & TDZ & & \\
\hline 0 & 0 & 0 & 0 & $1.75 \pm 0.25 a b c$ & - \\
\hline 0.1 & & & & $1.90 \pm 0.23 a b c$ & - \\
\hline 0.3 & & & & $1.83 \pm 0.30 \mathrm{abc}$ & - \\
\hline 0.5 & & & & $2.00 \pm 0.25 a b c$ & C \\
\hline \multirow[t]{13}{*}{0.7} & & & & $2.16 \pm 0.65 b c$ & C \\
\hline & 0.1 & & & $4.11 \pm 0.35 d$ & - \\
\hline & 0.3 & & & $2.50 \pm 0.42 \mathrm{c}$ & - \\
\hline & 0.5 & & & $2.00 \pm 0.54 a b c$ & C \\
\hline & 0.7 & & & $1.75 \pm 0.48 \mathrm{abc}$ & C \\
\hline & & 0.1 & & $1.14 \pm 0.14 a b$ & $\mathrm{~N}$ \\
\hline & & 0.3 & & $1.33 \pm 0.21 a b$ & $\mathrm{C}, \mathrm{N}$ \\
\hline & & 0.5 & & $1.25 \pm 0.25 a b$ & $\mathrm{C}, \mathrm{N}$ \\
\hline & & 0.7 & & $1.75 \pm 0.48 \mathrm{abc}$ & $\mathrm{C}, \mathrm{N}$ \\
\hline & & & 0.1 & $1.16 \pm 0.17 a b$ & C \\
\hline & & & 0.3 & $1.00 \pm 0.17 a$ & $\mathrm{C}$ \\
\hline & & & 0.5 & $1.50 \pm 0.29 a b c$ & $\mathrm{C}$ \\
\hline & & & 0.7 & $1.00 \pm 0.22 a$ & $\mathrm{C}$ \\
\hline
\end{tabular}

Mean values in a column, followed by different letters, are significantly different according to the Duncan's multiple range test $(P<0.05)$

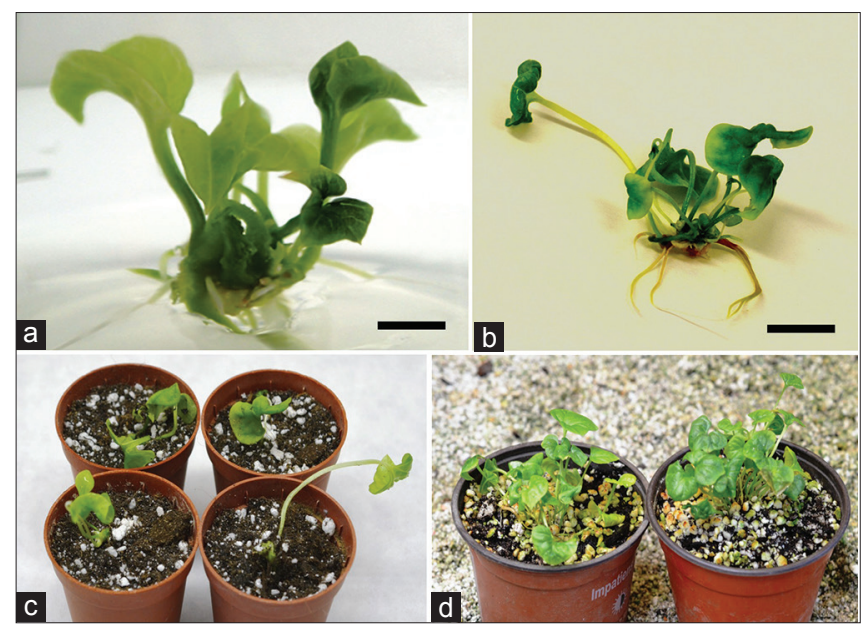

Fig 1. Shoot organogenesis, in vitro rooting and ex vitro transfer of $T$. leontopetaloides plants. (a) Shoot organogenesis of plants on MS medium supplemented with $0.1 \mathrm{mg} \mathrm{l}^{-1}$ zeatin after eight weeks of in vitro cultivation (bar $=1 \mathrm{~cm}$ ). (b) Shoot organogenesis and in vitro rooting of plants on MS medium with addition of $0.1 \mathrm{mg} \mathrm{l}^{-1}$ zeatin and $0.05 \mathrm{mg} \mathrm{l}^{-1}$ NAA after eight weeks of in vitro cultivation (bar $=1.5 \mathrm{~cm}$ ). (c) Plants divided into individual shoots and transferred ex vitro $(\mathrm{bar}=3 \mathrm{~cm})$. (d) Plants three weeks after ex vitro transfer $(\mathrm{bar}=4 \mathrm{~cm})$.

Cetiner, 2014), in vitro propagation using zeatin led to improvements of previously published protocols, based on the application of other cytokinins (Cenkci et al., 2009; Grevenstuk et al., 2010). On the other hand, for numerous species from the Dioscoreaceae family, BA still remains sufficiently effective for in vitro propagation, e.g., for T. chantrieri (Charoensub et al., 2008), Dioscorea multiflora (de Souza et al., 2011), D. zingiberensis (Chen et al., 2003), and. D. fordii (Yan et al., 2011).
In other species of the Dioscorea genus (D. rotundata, $D$. cayenensis, and $D$. alata), a comparative study of various cytokinins on shoot organogenesis has been carried out. It has been demonstrated that the highest responsiveness of shoot organogenesis is obtained using kinetin, followed by BA and zeatin (Anike et al., 2012). These results represent the inverse order as found with T. leontopetaloides, where kinetin provided markedly unsatisfactory results. In our experiment, although addition of kinetin at low concentrations led to the formation of a few shoots, the shoots produced, showed weak growth, and had developed small and transparent leaves. Kinetin at higher concentrations primarily resulted in callus formation before shoot development, and the shoots were even smaller than those developed on media with a lower kinetin concentration. Furthermore, after eight weeks of culture, many plants did not survive.

Even less efficient was medium containing thidiazuron, which almost failed to produce shoots. In addition, a yellowish green callus was produced at all TDZ concentrations tested. The effect of thidiazuron on species from the family Dioscoreaceae has not been reported to date; and in this regard, our experiment provided valuable data. Nevertheless, thidiazuron is being used with success in some species to increase the number of shoots, e.g., in interspecific hybrids of Glandularia (Gonzalez et al., 2015), or Zea mays (Ramakrishnan et al., 2014).

\section{Effect of combination of cytokinin and auxin on shoot organogenesis and in vitro rooting}

In the second phase of the experiment, the effect of the combination of cytokinin and auxin on shoot organogenesis and in vitro rhizogenesis was tested. In the previous study of Borokini et al. (2011), the addition of auxin (NAA) to the initially tested cytokinin (BA) significantly increased shoot organogenesis. Thus, the most efficient medium optimized in the first phase of our experiment, i.e., $0.1 \mathrm{mg}$ $\mathrm{l}^{-1}$ zeatin was combined with NAA or IAA (0.01-0.07 $\left.\mathrm{mg} \mathrm{l}^{-1}\right)$.

However, our results showed that auxins, regardless of their type or concentration, neither significantly increased nor decreased shoot production; shoot multiplication remained comparable as in the treatment without auxins (Table 2). This data indicates that for the in vitro propagation of this species, addition of zeatin is sufficient, and combination with auxin is not needed.

On the other hand, by the addition of auxins, a tendency to an increased rooting was observed. All explants on tested media containing auxins, produced roots. Except for the highest IAA and NAA concentrations tested (i.e., $0.07 \mathrm{mg}$ $\left.1^{-1}\right)$, the number of roots increased with the concentration of both auxins (Table 2). The highest number of roots was 


\begin{tabular}{|c|c|c|c|c|}
\hline \multicolumn{3}{|c|}{ PGR concentration $\left(\mathrm{mg} \mathrm{l}^{-1}\right)$} & \multicolumn{2}{|c|}{ Mean \pm S.E. } \\
\hline Zeatin & NAA & IAA & $\begin{array}{l}\text { Number of } \\
\text { roots/explant }\end{array}$ & $\begin{array}{c}\text { Number of } \\
\text { shoots/explant }\end{array}$ \\
\hline 0 & 0 & 0 & $1.13 \pm 0.13 a$ & $1.75 \pm 0.25 b$ \\
\hline 0.1 & 0 & 0 & $2.67 \pm 0.24 b$ & $4.11 \pm 0.35 a$ \\
\hline 0.1 & 0.01 & & $3.43 \pm 0.20 b c$ & $3.71 \pm 0.42 a$ \\
\hline 0.1 & 0.03 & & $3.50 \pm 0.50 \mathrm{bc}$ & $3.17 \pm 0.70 a$ \\
\hline 0.1 & 0.05 & & $5.00 \pm 0.38 \mathrm{e}$ & $3.63 \pm 0.38 a$ \\
\hline 0.1 & 0.07 & & $4.33 \pm 0.21 \mathrm{cde}$ & $3.33 \pm 0.33 a$ \\
\hline 0.1 & & 0.01 & $3.44 \pm 0.34 \mathrm{bc}$ & $3.00 \pm 0.41 a$ \\
\hline 0.1 & & 0.03 & $3.50 \pm 0.34 \mathrm{bc}$ & $3.33 \pm 0.42 a$ \\
\hline 0.1 & & 0.05 & $4.57 \pm 0.43 \mathrm{de}$ & $3.29 \pm 0.47 a$ \\
\hline 0.1 & & 0.07 & $3.71 \pm 0.42 \mathrm{bcd}$ & $3.00 \pm 0.53 a$ \\
\hline
\end{tabular}

Mean values in a column, followed by different letters, are significantly different according to the Duncan's multiple range test $(P<0.05)$

achieved on medium with $0.05 \mathrm{mg} \mathrm{l}^{-1} \mathrm{NAA}$, followed by medium supplemented with IAA at the same concentration. The former medium provided a more equal distribution and quality (length) of roots among all the developed shoots (data not shown), enabling separation of rooted shoots from the original explant, and their use for ex vitro transfer. Moreover, using this medium, a somewhat higher number of roots and shoots was achieved, than in the latter medium. From this perspective, $0.05 \mathrm{mg} \mathrm{l}^{-1} \mathrm{NAA}$ might be considered as the most appropriate treatment.

Our results are in accord with the study of Charoensub et al. (2008), where NAA was also successfully used for in vitro rooting of Tacca chantrieri. However, double the concentration as compared to T. leontopetaloides, was reported to be optimal. In our experiment, higher NAA concentrations tended to reduce root numbers, indicating that lower concentrations provide better results in this species. In Dioscorea remotiflora and D. zingiberensis, exogenous addition of NAA induced callus/or shoot formation; whereas IBA was essential to root induction (BernabeAntonio et al., 2012; Chen et al., 2003). In these species, IBA concentrations ranging between 1-2 $\mathrm{mg} \mathrm{l}^{-1}$ provided satisfactory results in terms of in vitro rooting.

In our study, medium optimized by combining zeatin and NAA, enables in vitro propagation and rooting of plants in one step (Fig. 1b). Thus, the producers can shorten the micropropagation period by omitting a rooting phase. The rooted plants can be taken anytime from the multiplication process. Additionally, unlike a regular rooting stage, on the medium described here, plants further proliferate while each shoot develops its own root system.

\section{Ex vitro transfer}

The plants of $T$. leontopetaloides taken from the medium supplemented with $0.1 \mathrm{mg} \mathrm{l}^{-1}$ zeatin and $0.05 \mathrm{mg} \mathrm{l}^{-1} \mathrm{NAA}$ were divided into rooted-shoots, which were used for ex vitro transfer (Fig. 1c). A total of 90 plants each with at least two roots that were minimally $1 \mathrm{~cm}$ long were transferred to ex vitro conditions, as described in the methodology. After 8 weeks of culture, the survival rate of plants reached $97.78 \%$. No morphological abnormalities appeared, and the plants developed new leaves. Further, the plants were continuously growing (Fig. 1d). These results are completely comparable with other experiments conducted in species of the taxonomically related genus Dioscorea, e.g., in D. oppositifolia (Behera et al., 2009), and in D. rotundata, D. cayenensis, D. alata and D. trifida (Asemota et al., 1997).

\section{ISSR and flow cytomeric analyses}

From the most effective treatment $\left(0.1 \mathrm{mg} \mathrm{l}^{-1}\right.$ zeatin in combination with $\left.0.05 \mathrm{mg} \mathrm{l}^{-1} \mathrm{NAA}\right), 10$ plantlets were randomly chosen and then subjected to ISSR and flow cytometric analyses to reveal potential somaclonal variation among in vitro regenerants.

For ISSR analysis, a total of 30 primers were initially tested, out of which 11 primers produced clear and reproducible fragments, ranging from 2 to 7 bands per primer. These ISSR primers were used for further analysis. They scored a total of 440 bands with an average of 3.64 bands per primer. The highest number of scored fragments was generated by UBC826 (7 bands), followed by UBC812 (6 bands), UBC809 and UBC810 (both 5 bands) (Table 3). The size of the amplification fragments ranged from 250 to $1900 \mathrm{bp}$. Monomorphic patterns across 10 in vitro regenerants and control plant were obtained, indicating no genetic variation among plantlets. Fig. 2a shows monomorphic amplification patterns obtained with ISSR primer UBC812.

In previous studies, ISSR was reported to be a reliable method to reveal potential occurrences of somaclonal variation. Using this technique, genetic variation was successfully detected, e.g., in plants of Smallanthus sonchifolius regenerated via indirect somatic embryogenesis (Viehmannova et al., 2014), or in plantlets of Robinia ambigua obtained via enhanced branching of axillary buds (Guo et al., 2006). In our study, ISSR analysis showed no variation, indicating genetic fidelity among in vitro regenerated plantlets. Comparably high levels of monomorphism among in vitro regenerants were reported for Gynura bicolor plants obtained via indirect shoot organogenesis (Liu et al., 2011a), and for Hydrangea macrophylla plants obtained through direct organogenesis (Liu et al., 2011b).

Neither flow cytometric analysis revealed variation among in vitro regenerants of Tacca leontopetaloides. In all samples, flow cytometric linear histograms of relative nuclear 
Table 3: ISSR primers, primer sequences, annealing temperatures, numbers and sizes of amplified fragments

\begin{tabular}{|c|c|c|c|c|c|}
\hline $\begin{array}{l}\text { Primers } \\
\text { code (UBC) }\end{array}$ & $\begin{array}{l}\text { Sequence } \\
5^{\prime}-3^{\prime}\end{array}$ & $\begin{array}{c}\text { Annealing } \\
\text { temperature }\left({ }^{\circ} \mathrm{C}\right)\end{array}$ & $\begin{array}{l}\text { Total number of } \\
\text { bands amplified }\end{array}$ & $\begin{array}{l}\text { Number of scorable } \\
\text { bands per primer }\end{array}$ & $\begin{array}{c}\text { Range of } \\
\text { amplification }(\mathrm{pb})\end{array}$ \\
\hline UBC807 & $(A G)_{8}{ }^{T}$ & 46.5 & 33 & 3 & $500-850$ \\
\hline UBC809 & $(A G)_{8} G$ & 55.0 & 55 & 5 & $250-1750$ \\
\hline UBC810 & $(\mathrm{GA})_{8} \mathrm{~T}$ & 50.2 & 55 & 5 & $350-1000$ \\
\hline UBC812 & $(\mathrm{GA})_{8} \mathrm{~A}$ & 50.2 & 66 & 6 & $450-1300$ \\
\hline UBC826 & $(\mathrm{AC})_{8} \mathrm{C}$ & 50.2 & 77 & 7 & $550-1600$ \\
\hline UBC828 & $(\mathrm{TG})_{8} \mathrm{~A}$ & 48.5 & 33 & 3 & $500-1900$ \\
\hline UBC835 & $(A G)_{8} Y C$ & 49.0 & 22 & 2 & $550-700$ \\
\hline UBC836 & $(A G)_{8} Y A$ & 49.0 & 22 & 2 & $1300-1600$ \\
\hline UBC840 & $(\mathrm{GA})_{8} \mathrm{YT}$ & 48.5 & 33 & 3 & $400-1000$ \\
\hline UBC845 & $(\mathrm{CT})_{8} \mathrm{RG}$ & 50.2 & 22 & 2 & $650-1400$ \\
\hline UBC855 & $(\mathrm{AC})_{8} \mathrm{YT}$ & 48.5 & 22 & 2 & $700-1300$ \\
\hline Total & & & 440 & 40 & \\
\hline
\end{tabular}

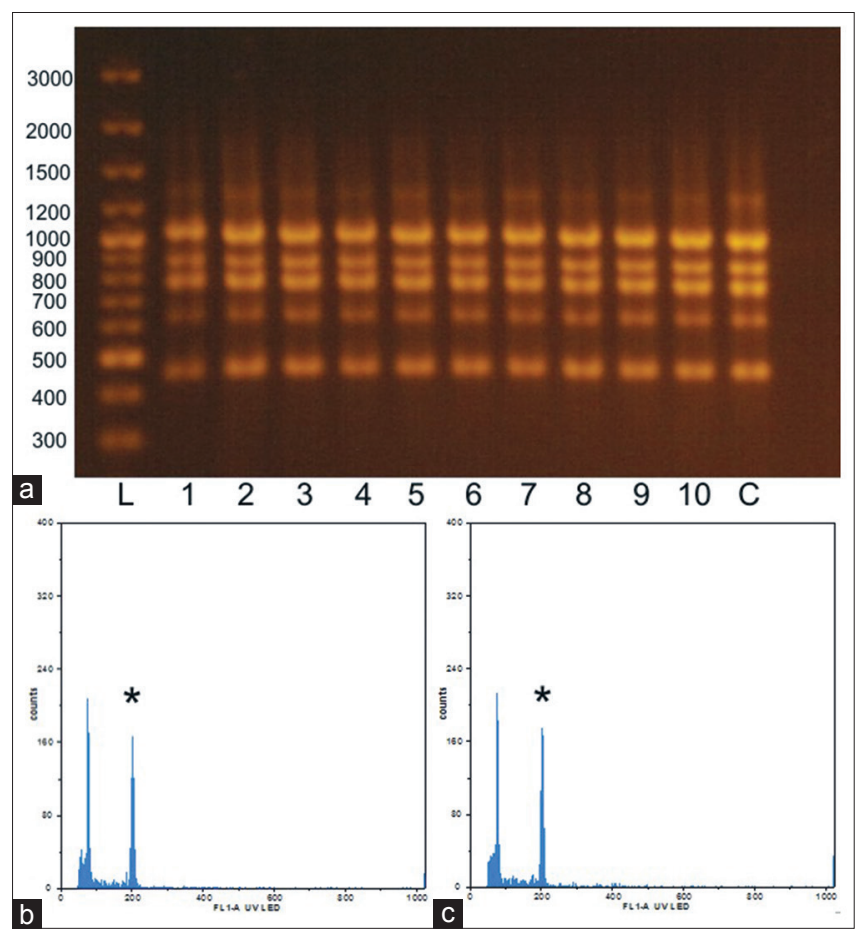

Fig 2. Assessment of in vitro regenerants of $T$. leontopetaloides using ISSR and flow cytometric analysis. (a) ISSR profile of control plant and in vitro regenerants (1-10) of $T$. leontopetaloides using primer 'UBC812' (C - control plant. $\mathrm{L}$ - ladder). (b, c) Flow cytometric histograms of DAPI stained nuclei of control plant and a randomly chosen in vitro regenerated plant. Peak indicated as "* " corresponds to the internal reference standard Glycine max.

content showed two peaks; the first corresponding to the nuclei of an analysed sample of T. leontopetaloides in the G0/G1 phase, and the second peak representing the G0/ G1 nuclei of the internal standard Glycine max in the G0/ G1 phase (Fig. 2b, c). Coefficients of variation of G0/ G1 peaks belonging to $T$. leontopetaloides samples ranged between 2.21-3.28\%. Differences of DNA-ratios showed no significant variation (0.381-0.289), indicating stability of ploidy level across the in vitro regenerans.
Somaclonal variation is a very complex phenomenon, which requires the use of different approaches to be correctly evaluated (Fourre et al., 1997). Analysis of ploidy level variation is a useful complementary approach to molecular analysis, which only enables revealing mutations linked to these markers; whilst genomic changes might remain undetected (Jin et al., 2008; Raimondi et al., 2001). Variation in ploidy level after in vitro propagation was detected in many species, e.g., in Titanotrichum oldhamii (Takagi et al., 2011), Cucurbita pepo (Kathiravan et al., 2006), and in Populus x beijingensis (Huang et al., 2015). Thus, development of an efficient system for assessment of in vitro regenerants, making it possible to reveal both molecular and genomic changes, seems to be highly advisable.

\section{CONCLUSION}

In this study, a novel simplified protocol for micropropagation of $T$. leontopetaloides was developed; enabling propagation and rooting of plants in one step. In the first phase, by comparing various cytokinins, zeatin was found to be the most efficient for in vitro propagation via shoot organogenesis at a concentration of $0.1 \mathrm{mg} \mathrm{l}^{-1}$. Subsequently, its combination with $0.05 \mathrm{mg} \mathrm{l}^{-1}$ NAA provided not only equally high rate of propagation, but also a satisfactory rooting efficiency enabling ex vitro transfer of the plantlets. No molecular and genomic changes were revealed among in vitro regenerants, indicating that the micropropagation protocol described here could be employed for effective mass production of true-to-type plants of this species.

\section{ACKNOWLEDGEMENT}

This research was financially supported by the Internal Grant Agency of the Czech University of Life Science 
Prague CIGA (Project No. 20135002); also by the Internal Grant Agency of the Faculty of Tropical AgriSciences, Czech University of Life Sciences Prague IGA (Project No. 20145020).

\section{Author contributions}

Petra Hlasna Cepkova conducted molecular analysis, Jan Vitamvas analysed samples using flow cytometer, Jana Kisilova carried out in vitro experiments, Iva Viehmannova conceived the idea, designed the experiments and prepared the manuscript, Eloy Fernandez Cusimamani was involved in literature collection, and Luigi Milella statistically analysed the results.

\section{REFERENCES}

Adhikari, S., T. K. Bandyopadhyay and P. Ghosh. 2014. Assessment of genetic stability of Cucumis sativus L. regenerated from encapsulated shoot tips. Sci. Hortic. 170: 115-122.

Anike, F. N., K. Konan, K. Olivier and H. Dodo. 2012. Efficient shoot organogenesis in petioles of yam (Dioscorea spp). Plant Cell Tissue Organ Cult. 111: 303-313.

Asemota, H. N., O. A. lyare, A. O. Wheatley and M. H. Ahmad. 1997. Acclimatization of in vitro grown yam (Dioscorea spp.) plantlets and some enzyme changes. Trop. Agric. 74: 243-247.

Behera, K. K., S. Sahoo and A. Prusti. 2009. Regeneration of plantlets of water yam (Dioscorea oppositifolia L.) through in vitro culture from nodal segments. Not. Bot. Hortic. Agrobot. Cluj-Napoca. 37: 94-102.

Bernabe-Antonio, A., F. S. Ruvalcaba and F. Cruz-Sosa. 2012. Effect of plant growth regulators on plant regeneration of Dioscorea remotiflora (Kunth) through nodal explants. Plant Growth Regul. 68: 293-301.

Borokini, T. I., E. F. Lawyer and A. E. Ayodele. 2011. In vitro propagation of Tacca leontopetaloides (L.) Kuntze in Nigeria. Egypt. J. Biol. 13: 51-56.

Cenkci, S., M. Temel, M. Kargioglu and S. Dayan. 2009. Propagation of endangered Thermopsis turcica Kit Tan, Vural \& Kucukoduk using conventional and in vitro techniques. Turk. J. Biol. 33: 327-333.

Charoensub, R., D. Thiantong and S. Phansiri. 2008. Micropropagation of bat flower plant, Tacca chantrieri Andre. Kasetsartz J. (Nat. Sci.). 42: 7-12.

Chen, Y., J. Fan, F. Yi, Z. Luo and Y. Fu. (2003). Rapid clonal propagation of Dioscorea zingiberensis. Plant Cell Tissue Organ Cult. 73: 75-80.

de Souza, A. V., B. W. Bertoni, S., S. C. Franca and A. M. S. Pereira. 2011. Micropropagation of dioscorea multiflora grised. Cienc. Agrotec. 35: 92-98.

Dolezel, J., M. Dolezelova and F. J. Novak. 1994. Flow cytometric estimation of nuclear DNA amount in diploid bananas (Musa acuminata and M. balbisiana). Biol. Plant. 36: 351-357.

Dolezel, J., J. Greilhuber and J. Suda. 2007. Estimation of nuclear DNA content in plants using flow cytometry. Nat. Protoc. 2: 22332244.

Doyle, J. and J. L. Doyle. 1987. Genomic plant DNA preparation from fresh tissue-CTAB method. Phytochem. Bull. 19: 11-15.

Engelmann, F. 2011. Use of biotechnologies for the conservation of plant biodiversity. in vitro Cell. Dev. Biol. Plant. 47: 5-16.
Fourre, J. L., P. Berger, L. Niquet and P. Andre. 1997. Somatic embryogenesis and somaclonal variation in Norway spruce: Morphogenetic, cytogenetic and molecular approaches. Theor. Appl. Genet. 94: 159-169.

Gonzalez, L. R., J. lannicelli, A. Coviella, V. Bugallo, P. Bologna, S. Pitta-Alvarez and A. Escandon. 2015. A protocol for the in vitro propagation and polyploidization of an interspecific hybrid of Glandularia (G. peruviana x G. scrobiculata). Sci. Hortic. 184: 46-54.

Grevenstuk, T., N. Coelho, S. Gonçalves and A. Romano. 2010. In vitro propagation of Drosera intermedia in a single step. Biol. Plant. 54: 391-394.

Guo, W. L., Y. D. Li, L. Gong, F. X. Li, Y. S. Dong and B. Liu. 2006. Efficient micropropagation of Robinia ambigua var. idahoensis (Idaho Locust) and detection of genomic variation by ISSR markers. Plant Cell Tissue Organ Cult. 84: 343-351.

Huang, Z., C. P. Xu, Y. Li, P. Q. Wang, Y. Li and X. Y. Kang. 2015. Induction of somatic embryogenesis by anther-derived callus culture and plantlet ploidy determination in poplar (Populus $\mathrm{x}$ beijingensis). Plant Cell Tissue Organ Cult. 120: 949-959.

Jin, S. X., R. Mushke, H. G. Zhu, L. L. Tu, Z. X. Lin, Y. X. Zhang and X. L. Zhang. 2008. Detection of somaclonal variation of cotton (Gossypium hirsutum) using cytogenetics, flow cytometry and molecular markers. Plant Cell Rep. 27: 1303-1316.

Kathiravan, K., G. Vengedesan, S. Singer, B. Steinitz, H. S. Paris and V. Gaba. 2006. Adventitious regeneration in vitro occurs across a wide spectrum of squash (Cucurbita pepo) genotypes. Plant Cell Tissue Organ Cult. 85: 285-295.

Kay, D. E. 1987. In: Gooding, E. G. B (Ed.), Root Crops. 2nd ed. Tropical Development and Research Institute, UK London, p. 380.

Liu, L. S., R. Li, Y. Zhao, C. L. Wen, S. Ren and Y. D. Guo. 2011a. High efficiency regeneration and genetic stability analysis of somatic clones of Gynura bicolor DC. Afr. J. Biotechnol. 10: 10380-10386.

Liu, F., L. L. Huang, Y. L. Li, P. Reinhoud, M. A. Jongsma and C. Y. Wang. 2011b. Shoot organogenesis in leaf explants of Hydrangea macrophylla 'Hyd1' and assessing genetic stability of regenerants using ISSR markers. Plant Cell Tissue Organ Cult. 104: 111-117.

Makhtar, N. S. M., M. F. M. Rais, M. N. M. Rodhi, N. Bujang, M. Musa and K. H. K. Hamid. 2013. Tacca leontopetaloides starch: New sources starch for biodegradable plastics. Int. Tribol. Conf. Malays. 68: 385-391.

Murashige, T. and F. Skoog. 1962. A revised medium for rapid growth and bioassays with tobacco tissue cultures. Physiol. Plant. 15: 473-497.

Raimondi, J. P., R. W. Masuelli and E. L. Camadro. 2001. Assessment of somaclonal variation in asparagus by RAPD fingerprinting and cytogenetic analyses. Sci. Hortic. 90: 19-29.

Ramakrishnan, M., S. A. Ceasar, V. Duraipandiyan and S. Ignacimuthu. 2014. Efficient plant regeneration from shoot apex explants of maize (Zea mays) and analysis of genetic fidelity of regenerated plants by ISSR markers. Plant Cell Tissue Organ Cult. 119: 183-196.

Rejthar, J., I. Viehmannova, P. Hlasna Cepkova, E. Fernandez and L. Milella. 2014. In vitro propagation of Drosera intermedia as influenced by cytokinins, $\mathrm{pH}$, sucrose, and nutriet concentration. Emirates J. Food Agric. 26: 558-564.

Spennemann, D. H. R. 1994. Traditional arrowroot production and utilization in the Marshall Islands. J. Ethnobiol. 14: 211-234.

Takagi, H., S. Sugawara, T. Saito, H. Tasaki, X. Y. Lu, K. Y. Guan, D. S. Han, T. Godo and M. Nakano. 2011. Plant regeneration 
via direct and indirect adventitious shoot formation and chromosome-doubled somaclonal variation in Titanotrichum oldhamii (Hemsl.) Solereder. Plant Biotechnol. Rep. 5: 187-195.

Tekdal, D. and S. Cetiner. 2014. In vitro plant regeneration derived from leaf and stem explants of endemic Thermopsis turcica. Biol. 69: 863-869.

Ubwa, S. T., B. A. Anhwange and J. T. Chia. 2011. Chemical analysis of Tacca leontopetaloides peels. Am. J. Food Technol. 6: 932938.

Ukpabi, U. J., E. Ukenye and A. O. Olojede. 2009. Raw-material potential of Nigerian wild Polynesian arrowroot (Tacca leontopetaloides) tubers and starch. J. Food Technol. 7: 135138.

Viehmannova, I., Z. Bortlova, J. Vitamvas, P. Hlasna Cepkova, K. Eliasova, E. Svobodova and M. Travnickova. 2014. Assessment of somaclonal variation in somatic embryo-derived plants of yacon [Smallanthus sonchifolius (Poepp. and Endl.) $\mathrm{H}$. Robinson] using inter simple sequence repeat analysis and flow cytometry. Electron. Biotechnol. 17: 102-106.

Yan, H., L. Yang and Y. Li. 2011. Axillary shoot proliferation and tuberization of Dioscorea fordii Prain et Burk. Plant Cell Tissue Organ Cult. 104: 193-198. 